\title{
Pertanggungjawaban Pidana Partai Politik dalam Tindak Pidana Korupsi dan Pencucian Uang
}

\author{
Russel Butarbutar*
}

\begin{abstract}
Abstrak
Pertanggungjawaban pidana korupsi dan pencucian uang selama ini sering hanya dikenakan pada 'orang' sebagai subjek pelaku. Salah satu tindak pidana korupsi yang akhir-akhir ini sering terjadi adalah yang berasal dari partai politik, yang dilakukan oleh anggotanya. Dalam praktik, sulit mengidentifikasi perbuatan personel partai politik itu menjadi perbuatan yang dapat dipertanggungjawabkan kepada partai politik. Artikel ini menggali hal-hal yang berkaitan dengan pertanggungjawaban pidana partai politik dalam tindak pidana korupsi dan pencucian uang. Negara dapat meminta pertanggungjawaban pidana karena partai politik dapat dikategorikan sebagai korporasi. Partai politik merupakan subjek hukum yang dapat dimintakan pertanggungjawaban pidana dalam hal personel atau pengurusnya melakukan tindak pidana korupsi berdasarkan teori pemidanaan terhadap korporasi. Ketentuan hukum juga telah mengatur bentuk sanksi pidana berupa denda, pengumuman putusan hakim, pembekuan sebagian atau seluruh kegiatan usaha partai, pencabutan izin operasional partai, pembubaran dan/atau pelarangan partai, perampasan aset partai untuk negara, dan/atau pengambilalihan partai politik oleh negara.
\end{abstract}

Kata kunci: korupsi, partai politik, pencucian uang, pertanggungjawaban, pidana.

\section{Criminal Liability of Political Parties for Corruption and Money Laundering}

\begin{abstract}
Criminal responsibility of corruption and money laundering is often imposed to individual as the perpetrators, whereas currently the trend shows that corruption is often performed by a political party through its personnel. In practice, it is difficult to identify which personal action taken by a personnel of a political party that could constitute as a criminal offence accountable to the political party. This article will discuss the matters surrounding criminal responsibility of a political party in regards to both corruption and money laundering. Political party as a subject of law is entitled to criminal responsibility in a case where its personnel or its officials is found guilty of corruption based on the criminal prosecution againsts corporation theory. Furthermore, legal provisions have also regulate criminal sanctions such as: financial penalties, announcement of court decision, freezing part or all of the business activities of the party, operational license revocation, dissolution and/or prohibition of the party, expropriation of assets to the state, and/or takeover of political party by the state.
\end{abstract}

Keywords: corruption, political parties, money laundering, responsibility, criminal.

PADJADJARAN Jurnal IImu Hukum Volume 3 Nomor 2 Tahun 2016 [ISSN 2460-1543] [e-ISSN 2442-9325]

* Dosen Fakultas Hukum Universitas Bung Karno, Jl. Pegangsaan Timur No. 17 Menteng, Jakarta, russelbutar@gmail.com, S.H. (Universitas Bung Karno), M.H. (Universitas Jayabaya), S.T. (Universitas Sumatera Utara), M.M. (Universitas Indonesia). 


\section{A. Pendahuluan}

Tindak pidana korupsi bisa dilakukan oleh siapa saja, baik perorangan, perusahaan berbadan hukum atau tidak berbadan hukum, organisasi masyarakat, koperasi, yayasan, dan anggota partai politik. Salah satu pelaku tindak pidana korupsi yang akhir-akhir ini sering terjadi adalah yang berasal dari partai politik, yang dilakukan oleh anggota partai politik baik yang duduk di lembaga legislatif, lembaga eksekutif, maupun yang bekerja di kepengurusan partai politik (kader partai politik) tersebut.

Indonesia menghadapi masalah korupsi yang sangat tinggi, pada tahun 2014 memiliki skor 34 dan menempati urutan 107 dari 175 negara. Skor Corruption Perception Index (CPI) Indonesia 2014 naik 2 poin sementara peringkat naik 7 (tujuh) peringkat dari tahun sebelumnya. ${ }^{1}$ Meskipun demikian, peringkat Indonesia masih jauh di bawah negara-negara tetangga seperti Filipina, Thailand, Malaysia, dan Singapura.

Mengacu kepada Undang-Undang Nomor 31 Tahun 1999 jo. Undang-Undang Nomor 20 Tahun 2001 tentang Pemberantasan Tindak Pidana Korupsi (UU Tipikor), perbuatan tindak pidana korupsi diklasifikasikan menjadi 7 (tujuh) jenis, yakni: merugikan keuangan negara, suap, gratifikasi, penggelapan dalam jabatan, pemerasan, perbuatan curang, dan konflik kepentingan. ${ }^{2}$

Menurut penelitian Pusat Kajian Anti Korupsi Universitas Gadjah Mada ${ }^{3}$ menyimpulkan seluruh partai politik yang memiliki perwakilan di Dewan Perwakilan Rakyat (DPR) maupun yang menjabat sebagai menteri di Kabinet Indonesia Bersatu 2009-2014 terlibat kasus korupsi (tidak ada satu pun partai yang memiliki kader yang menduduki jabatan publik yang tidak memiliki kaitan dengan praktik korupsi). Terkait dugaan korupsi politik, Partai Demokrat memiliki kedudukan pertama dengan persentase 28,40\%, disusul Partai Hanura (23,50\%), PDIP (18,08\%), PKS $(17,24 \%)$, Partai Golkar (16,03\%), PKB (14,28\%), PPP (13,16\%), dan Partai Gerindra $(3,85 \%)$. Partai Golkar diduga terlibat kasus pengadaan Al-Quran Kementerian Agama, kasus pemerasan Badan Usaha Milik Negara (BUMN), kasus Pekan Olahraga Nasional (PON) Riau, serta kasus Satuan Kerja Khusus Pelaksana Kegiatan Usaha Hulu Minyak dan Gas Bumi (SKK Migas). PDIP diduga terlibat kasus suap deputi Gubernur Senior Bank Indonesia (BI), kasus E-KTP, serta kasus simulator. ${ }^{4}$

1 Transparency International, “Corruption Perception Index 2014”, http://www.ti.or.id/index.php/publication/ 2014/12/06/corruption-perceptions-index-2014, diunduh 20 Mei 2015.

2 Indonesia Corruption Watch (ICW), "Modul Monitoring Penegakan Hukum", 2012, http://www.antikorupsi.org/sites/antikorupsi.org/files/doc/Modul/modulmonitoringpenegakanhukum.pdf

3 Pukat, "Seluruh Parpol Terlibat Kasus Korupsi", http://www.hukumonline.com/berita/baca/lt5329627e98607/pukat--seluruh-parpol-terlibat-kasus-korupsi, diakses 22 Oktober 2015.

4 Ibid. 
Tabel. 1.1 Kasus Korupsi yang melibatkan Personel Partai Politik ${ }^{5}$

\begin{tabular}{|c|c|c|c|c|}
\hline No & Nama Pelaku & Jabatan dalam Partai & $\begin{array}{l}\text { Jabatan Pekerjaan } \\
\text { Ketika Terkena }\end{array}$ & Kasus \\
\hline- & - & - & Kasus & + \\
\hline 1 & Angelina Sondakh & $\begin{array}{l}\text { Wakil Sekjen Partai } \\
\text { Demokrat }\end{array}$ & Anggota DPRRI & $\begin{array}{l}\text { Korupsi pembangunan wisma atlet dan } \\
\text { gedung serbaguna sumatera selatan } \\
2010-2011\end{array}$ \\
\hline 2 & $\begin{array}{l}\text { Muhammad } \\
\text { Nazaruddin }\end{array}$ & $\begin{array}{l}\text { Bendahara Partai } \\
\text { Demokrat }\end{array}$ & $\begin{array}{l}\text { Anggota Dewan } \\
\text { Perwakilan Rakyat } \\
\text { periode 2009-2014 }\end{array}$ & $\begin{array}{l}\text { Kasus suap proyek Wisma Atlet SEA } \\
\text { Game }\end{array}$ \\
\hline 3 & Andi Malaranggeng & $\begin{array}{l}\text { Sekretaris dan Anggota } \\
\text { Dewan Pembina serta } \\
\text { Sekretaris dan Anggota } \\
\text { Majelis Tinggi Partai } \\
\text { Demokrat }\end{array}$ & $\begin{array}{l}\text { Menteri Pemudan } \\
\text { dan Olahraga }\end{array}$ & Korupsi proyek Hambalang \\
\hline 4 & Anas Urbaningrum & $\begin{array}{l}\text { Ketuan Umum Partai } \\
\text { Demokrat }\end{array}$ & $\begin{array}{l}\text { Anggota DPRRi } \\
\text { 2009-2014, tetapi } \\
\text { mundur setelah } \\
\text { menjadi Ketua } \\
\text { Umum Demokrat }\end{array}$ & Terkait kasus Hambalang \\
\hline 5 & Luthfi Hassan Ishaag & Presiden Partai PKS & $\begin{array}{l}\text { Anggota DPR dari } \\
\text { Fraksi PKS periode } \\
2009-2014\end{array}$ & $\begin{array}{l}\text { Kasus pengurusan kuota impor daging } \\
\text { pada Kementerian Pertanian }\end{array}$ \\
\hline 6 & Gatot Pujo Nugroho & Kader PKS & $\begin{array}{l}\text { Gubernur Sumatera } \\
\text { Utara }\end{array}$ & $\begin{array}{l}\text { Dugaan kasus suap dan bantuan sosial } \\
\text { Propinsi Sumatera Utara }\end{array}$ \\
\hline 7 & Ratu Atut Chosiyah & $\begin{array}{l}\text { Ketua Bidang } \\
\text { Pemberdayaan } \\
\text { Perempuan Partai } \\
\text { Golkar }\end{array}$ & Gubernur Banten & $\begin{array}{l}\text { suap mantan Ketua Mahmakah } \\
\text { Konstitusi (MK) Akil Mochtar terkait } \\
\text { penyelesaian sengketa Pemilihan } \\
\text { Kepala Daerah Lebak, Banten. }\end{array}$ \\
\hline 8 & Suryadharma Ali & Ketua Umum PPP & Menteri Agama & $\begin{array}{l}\text { Dugaan korupsi penyelenggaraan ibadah } \\
\text { haji. }\end{array}$ \\
\hline 9 & Rachmat Yasin & Ketua DPD PPP Jabar & $\begin{array}{l}\text { Bupati Kabupaten } \\
\text { Bogor }\end{array}$ & $\begin{array}{l}\text { Suap alih fungsi kawasan hutan yang } \\
\text { mencapai } 2.754 \text { hektar menjadi Iahan } \\
\text { komersial oleh Kwee Cahyadi Kumala } \\
\text { alias Swie Teng, Komisaris Utama PT BJA } \\
\text { sekaligus Presiden Direktur City }\end{array}$ \\
\hline 10 & Emron Pangkapi & $\begin{array}{l}\text { Wakil Ketua Umum } \\
\text { PPP }\end{array}$ & Komisaris PT.Timah & $\begin{array}{l}\text { Penyalahgunaan Kredit Usaha Tani (KUT) } \\
\text { Jangkang Permai pada } 1999 \text { senilai Rp } \\
714,12 \text { juta dari total nilai kredit Rp } 1,259 \\
\text { miliar }\end{array}$ \\
\hline 11 & Yusuf Erwin Faisal & Kader PKB & $\begin{array}{l}\text { Ketua Komisi IV } \\
\text { DPR RI Periode } \\
\text { 2004-2009 dari } \\
\text { Partai Kebangkitan } \\
\text { Bangsa [PKB] }\end{array}$ & $\begin{array}{l}\text { Suap sebagai imbalan atas membantu } \\
\text { persetujuan anggaran pada program } \\
\text { revitalisasi gerakan nasional rehabilitasi } \\
\text { hutan dan lahan izin alih fungsi hutan } \\
\text { bakau di wilayah Tanjung Api-api, } \\
\text { Kabupaten Banyuasin, Sumatera Selatan }\end{array}$ \\
\hline 12 & $\begin{array}{l}\text { Al Amin Nur } \\
\text { Nasution }\end{array}$ & Kader PPP & & \\
\hline 13 & Adriansyah & Kader PDIP & Anggota DPRRI & $\begin{array}{l}\text { Suap PT Mitra Maju Sukses di Kabupaten } \\
\text { Tanah Laut Kalimantan Selatan terkait } \\
\text { ijin pertambangan }\end{array}$ \\
\hline 14 & Izedrik Emir Moeis & Kader PDIP & $\begin{array}{l}\text { Ketua Komisi XI } \\
\text { DPR }\end{array}$ & $\begin{array}{l}\text { Korupsi proyek pembangunan } \\
\text { Pembangkit Listrik Tenaga Uap, Tarahan, } \\
\text { Lampung }\end{array}$ \\
\hline 15 & Wa Ode Nurhayati & Kader PAN & $\begin{array}{l}\text { Anggota Banggar } \\
\text { DPRRI (2009-2014) }\end{array}$ & $\begin{array}{l}\text { kasus suap alokasi Dana Penyesuaian } \\
\text { Infrastruktur Daerah, DPID, tahun } 2011\end{array}$ \\
\hline 16 & Patrice Rio Capella & Sekjen Partai Nasdem & Anggota DPRRI & $\begin{array}{l}\text { Dugaan Suap kasus Gubernur Sumatera } \\
\text { Utara }\end{array}$ \\
\hline
\end{tabular}

5 Diolah Penulis dari berbagai sumber. 


\begin{tabular}{|c|c|c|c|c|}
\hline No & Nama Pelaku & Jabatan dalam Partai & $\begin{array}{l}\text { Jabatan Pekerjaan } \\
\text { Ketika Terkena }\end{array}$ & Kasus \\
\hline$\nabla$ & $\nabla$ & $\nabla$ & Kasus & $\nabla$ \\
\hline 18 & $\begin{array}{l}\text { Williem M } \\
\text { Tutuarima }\end{array}$ & Kader PDIP & Anggota DPRRI & $\begin{array}{l}\text { Suap pemilihan deputi gubernur senior } \\
\text { Bank Indonesia, Miranda Swaray } \\
\text { Goeltom }\end{array}$ \\
\hline 19 & Sutanto Pranoto & Kader PDIP & Anggota DPRRI & $\begin{array}{l}\text { Suap pemilihan deputi gubernur senior } \\
\text { Bank Indonesia, Miranda Swaray } \\
\text { Goeltom }\end{array}$ \\
\hline 20 & $\begin{array}{l}\text { Agus Chondro } \\
\text { Prayitno }\end{array}$ & Kader PDIP & Anggota DPRRI & $\begin{array}{l}\text { Suap pemilihan deputi gubernur senior } \\
\text { Bank Indonesia, Miranda Swaray } \\
\text { Goeltom }\end{array}$ \\
\hline 21 & M Iqbal & Kader PDIP & Anggota DPRRI & $\begin{array}{l}\text { Suap pemilihan deputi gubernur senior } \\
\text { Bank Indonesia, Miranda Swaray } \\
\text { Goeltom }\end{array}$ \\
\hline 22 & Budhiningsih & Kader PDIP & Anggota DPRRI & $\begin{array}{l}\text { Suap pemilihan deputi gubernur senior } \\
\text { Bank Indonesia, Miranda Swaray } \\
\text { Goeltom }\end{array}$ \\
\hline 23 & Poltak Sitorus & Kader PDIP & Anggota DPRRI & $\begin{array}{l}\text { Suap pemilihan deputi gubernur senior } \\
\text { Bank Indonesia, Miranda Swaray } \\
\text { Goeltom }\end{array}$ \\
\hline 24 & Aberson M Sihaloho & Kader PDIP & Anggota DPRRI & $\begin{array}{l}\text { Suap pemilihan deputi gubernur senior } \\
\text { Bank Indonesia, Miranda Swaray } \\
\text { Goeltom }\end{array}$ \\
\hline 25 & $\begin{array}{l}\text { Rusman Lumban } \\
\text { Toruan }\end{array}$ & Kader PDIP & Anggota DPRRI & $\begin{array}{l}\text { Suap pemilihan deputi gubernur senior } \\
\text { Bank Indonesia, Miranda Swaray } \\
\text { Goeltom }\end{array}$ \\
\hline 26 & Max Moein & Kader PDIP & Anggota DPRRI & $\begin{array}{l}\text { Suap pemilihan deputi gubernur senior } \\
\text { Bank Indonesia, Miranda Swaray } \\
\text { Goeltom }\end{array}$ \\
\hline 27 & $\begin{array}{l}\text { JeffeyTongas } \\
\text { Lumban Batu }\end{array}$ & Kader PDIP & Anggota DPRRI & $\begin{array}{l}\text { Suap pemilihan deputi gubernur senior } \\
\text { Bank Indonesia, Miranda Swaray } \\
\text { Goeltom }\end{array}$ \\
\hline 28 & Matheos Pormes & Kader PDIP & Anggota DPRRI & $\begin{array}{l}\text { Suap pemilihan deputi gubernur senior } \\
\text { Bank Indonesia, Miranda Swaray } \\
\text { Goeltom }\end{array}$ \\
\hline 29 & $\begin{array}{l}\text { Engelina A } \\
\text { Pattiasina }\end{array}$ & Kader PDIP & Anggota DPRRI & $\begin{array}{l}\text { Suap pemilihan deputi gubernur senior } \\
\text { Bank Indonesia, Miranda Swaray } \\
\text { Goeltom }\end{array}$ \\
\hline 30 & Suratal HW & Kader PDIP & Anggota DPRRI & $\begin{array}{l}\text { Suap pemilihan deputi gubernur senior } \\
\text { Bank Indonesia, Miranda Swaray } \\
\text { Goeltom }\end{array}$ \\
\hline 31 & $\begin{array}{l}\text { Ni Luh Mariani } \\
\text { Tirtasari }\end{array}$ & Kader PDIP & Anggota DPRRI & $\begin{array}{l}\text { Suap pemilihan deputi gubernur senior } \\
\text { Bank Indonesia, Miranda Swaray } \\
\text { Goeltom }\end{array}$ \\
\hline 32 & Soewarno & Kader PDIP & Anggota DPRRI & $\begin{array}{l}\text { Suap pemilihan deputi gubernur senior } \\
\text { Bank Indonesia, Miranda Swaray } \\
\text { Goeltom }\end{array}$ \\
\hline 33 & Emir Moeis & Kader PDIP & Anggota DPRRI & $\begin{array}{l}\text { Suap pemilihan deputi gubernur senior } \\
\text { Bank Indonesia, Miranda Swaray } \\
\text { Goeltom }\end{array}$ \\
\hline 34 & Sukarjo & Kader PDIP & Anggota DPRRI & $\begin{array}{l}\text { Suap pemilihan deputi gubernur senior } \\
\text { Bank Indonesia, Miranda Swaray } \\
\text { Goeltom }\end{array}$ \\
\hline
\end{tabular}


Selanjutnya, Partai Demokrat diduga terlibat kasus Hambalang, kasus pembangunan Wisma Atlet Palembang, kasus SKK Migas, kasus simulator SIM, kasus suap TVRI, dan kasus alkes Kemenkes. Partai Amanat Nasional (PAN) diduga terlibat pada kasus DPPID, kasus SKK Migas, dan kasus Hambalang. Sementara PPP diduga terlibat kasus bibit jagung Kementerian Pertanian, kasus SKK Migas, serta kasus Hambalang. ${ }^{6}$ Sementara itu, modus yang kerap terjadi dalam praktik korupsi antara lain modus suap, pemerasan terhadap sektor-sektor strategis, merugikan negara, memperdagangkan pengaruh, serta penyalahgunaan wewenang. ${ }^{7}$

Politik dan kapitalis menjadi sangat relevan dalam kehidupan demokrasi di Indonesia. Orang berpolitik dengan didasari oleh kalkulasi untung rugi. Ekspektasi dari tindakan politik adalah membawa mereka akan mendapat keuntungan ketika mereka terpilih. Untuk menjadi gubernur, seorang calon berani mengeluarkan biaya yang besar sekali, kalau perlu mendapatkan dukungan dari banyak partai. Dengan pertimbangan utama bahwa setelah menjadi gubernur, semua uang yang dikeluarkan untuk menjadi berkuasa itu akan bisa ditebus. Akibatnya negeri kita menjadi salah satu negara yang paling korup. ${ }^{8}$

Kemudian, besarnya dana yang dibutuhkan dalam rangka pembiayaan partai (political party financing) untuk membiayai mesin partai dalam rangka menjangkau pemilih yang lebih besar dan memenangkan kompetisi politik di Indonesia. Akhirnya partai politik ikut juga sebagai aktor korupsi di Indonesia, padahal seharusnya partai sebagai organisasi yang bersifat nasional dan dibentuk oleh sekelompok warga negara Indonesia secara sukarela atas dasar kesamaan kehendak dan cita-cita untuk memperjuangkan dan membela kepentingan politik anggota, masyarakat, bangsa dan negara, serta memelihara keutuhan Negara Kesatuan Republik Indonesia (NKRI) berdasarkan Pancasila dan Undang-Undang Dasar Negara Republik Indonesia Tahun 1945 (UUD 1945) ${ }^{9}$ harus menjadi panutan dan motor dalam pencegahan korupsi di Indonesia.

Bahaya korupsi khususnya kekuasaan politik yang dicapai dengan korupsi akan menghasilkan pemerintahan dan pemimpin masyarakat yang tidak legitimate di mata publik. Jika demikian keadaannya, maka masyarakat tidak akan percaya terhadap pemerintah dan pemimpin tersebut, akibatnya mereka tidak akan patuh dan tunduk pada otoritas mereka. Praktik korupsi yang meluas dalam politik seperti pemilu yang curang, kekerasan dalam pemilu, money politics, dan lain-lain juga

6 Hasil didapatkan melalui penelitian dengan metode analisa isi media yang memiliki rekam jejak kasus masingmasing kader yang dapat dijadikan bahan acuan melalui analisis yang berimbang.

Pukat, Loc.cit.

8 Firmanzah, Mengelola Partai Politik Komunikasi dan Positioning Ideologi Politik di Era Demokrasi, Jakarta: Pustaka Obor Indonesia, 2011, hlm. 25-26.

9 Pasal 1 ayat (1) Undang-Undang Nomor 2 Tahun 2011 tentang Perubahan atas Undang-Undang Nomor 2 Tahun 2008 tentang Partai Politik (UU Parpol). 
dapat menyebabkan rusaknya demokrasi, karena untuk mempertahankan kekuasaan, penguasa korup tersebut akan menggunakan kekerasan (otoriter) atau menyebarkan korupsi lebih luas lagi di masyarakat. ${ }^{10}$ Di samping itu, keadaan yang demikian itu akan memicu terjadinya instabilitas sosial politik dan integrasi sosial, karena terjadi pertentangan antara penguasa dan rakyat. Bahkan dalam banyak kasus, hal ini menyebabkan jatuhnya kekuasaan pemerintahan secara tidak terhormat, seperti yang terjadi di Indonesia. ${ }^{11}$

Sehubungan dengan bahaya korupsi yang dilakukan partai politik, partai politik seharusnya bisa dijadikan sebagai subjek hukum pidana yang dapat dipidana yang bertujuan untuk menakut-nakuti pengurus atau partai politik jangan sampai melakukan kejahatan (general preventie) maupun menakut-nakuti pengurus atau partai politik yang sudah menjalankan kejahatan agar di kemudian hari tidak melakukan kejahatan lagi (speciale preventie), dan untuk mendidik atau memperbaiki orang-orang atau pengurus atau partai politik yang sudah melakukan kejahatan agar menjadi pengurus atau partai politik yang baik tabiatnya sehingga bermanfaat bagi masyarakat. ${ }^{12}$

Untuk itu partai politik harus bisa diminta pertanggungjawabannya terhadap tindak pidana korupsi yang dilakukan oleh pengurusnya untuk menghindari kerusakan demokrasi dan bahaya laten yang diakibatkan oleh praktik korupsi di Indonesia, dan yang paling penting adalah memenuhi rasa keadilan masyarakat dan menciptakan etika dan budaya jujur politik dalam menjalankan demokrasi. Seperti halnya tujuan dari partai politik itu sendiri yang dibagi atas 2 (dua) tujuan, yaitu tujuan umum dan tujuan khusus.

Tujuan umum partai politik adalah: a) mewujudkan cita-cita nasional bangsa Indonesia sebagaimana dimaksud dalam Pembukaan UUD 1945; b) menjaga dan memelihara keutuhan NKRI; c) mengembangkan kehidupan demokrasi berdasarkan Pancasila dengan menjunjung tinggi kedaulatan rakyat dalam NKRI; dan d) mewujudkan kesejahteraan bagi seluruh rakyat Indonesia. Sedangkan tujuan khusus partai politik meliputi: a) meningkatkan partisipasi politik anggota dan masyarakat dalam rangka penyelenggaraan kegiatan politik dan pemerintahan; b) memperjuangkan cita-cita partai politik dalam kehidupan bermasyarakat, berbangsa, dan bernegara; dan c) membangun etika dan budaya politik dalam kehidupan bermasyarakat, berbangsa, dan bernegara. ${ }^{13}$

Dalam praktik, sangat sulit mengidentifikasi perbuatan personel partai politik itu menjadi perbuatan yang dapat dipertanggungjawabkan kepada partai politik

\footnotetext{
10 Arfan Faiz Muhlizi, "Revolusi Mental Untuk Membentuk Budaya Hukum Anti Korupsi", Jurnal Hukum RechtsVinding, Vol. 3, No. 3, 2014, hlm. 460.

11 Ibid.

12 Wirjono Prodjodikoro, Asas-Asas Hukum Pidana di Indonesia, Bandung: Refika Aditama, 2014, hIm. $19-20$.

13 Pasal 10 Ayat (1) dan (2) UU Parpol.
} 
tersebut. Untuk itu, Penulis berkeinginan untuk menggali hal-hal yang berkaitan dengan pertanggungjawaban pidana partai politik dalam tindak pidana korupsi.

Berdasarkan fakta-fakta yang disebutkan di atas, Penulis bertujuan menemukan gagasan konseptual tentang apakah partai politik termasuk badan hukum yang dapat dikenai pertanggungjawaban pidana dalam tindak pidana korupsi dan jenis sanksi pidana yang dapat dijatuhkan kepada partai politik yang melakukan tindak pidana korupsi. Pendekatan yang dipakai dalam penelitian ini adalah yuridis normatif dengan menggunakan data primer berupa undang-undang dan data sekunder berupa buku dan bahan pustaka lain seperti artikel dalam jurnal yang berbentuk buku maupun yang terdapat dalam internet. Semua bahan tersebut dipelajari secara seksama dan disajikan menjadi data dalam bentuk uraian dan tabel, kemudian data tersebut dianalisis menggunakan teori-teori hukum tentang pertanggungjawaban pidana korporasi dan perbandingan dalam peraturan perundang-undangan untuk menghasilkan kesimpulan dan saran.

\section{B. Pembahasan}

1. Partai Politik sebagai Badan Hukum dan Pertanggungjawaban Tindak Pidana Korupsi

Merujuk kepada pengaturan dalam Pasal 1 ayat (1) Undang-Undang Nomor 2 Tahun 2008 jo. Undang-Undang Nomor 2 Tahun 2011 tentang Partai Politik (UU Partai Politik) menyatakan:

"Partai Politik adalah organisasi yang bersifat nasional dan dibentuk oleh sekelompok warga negara Indonesia secara sukarela atas dasar kesamaan kehendak dan cita-cita untuk memperjuangkan dan membela kepentingan politik anggota, masyarakat, bangsa dan negara, serta memelihara keutuhan Negara Kesatuan Republik Indonesia berdasarkan Pancasila dan Undang-Undang Dasar Negara Republik Indonesia Tahun 1945."

Partai politik ini harus didaftarkan ke Kementerian untuk menjadi badan hukum. ${ }^{14}$ Untuk menjadi badan hukum, partai politik harus mempunyai: a) akta notaris pendirian partai politik; b) nama, lambang, atau tanda gambar yang tidak mempunyai persamaan pada pokoknya atau keseluruhannya dengan nama, lambang, atau tanda gambar yang telah dipakai secara sah oleh partai politik lain sesuai dengan peraturan perundang-undangan; c) kepengurusan pada setiap provinsi dan paling sedikit $75 \%$ dari jumlah kabupaten/kota pada provinsi yang bersangkutan dan paling sedikit $50 \%$ dari jumlah kecamatan pada kabupaten/kota yang bersangkutan; d) kantor tetap pada tingkatan pusat, provinsi, dan kabupaten

14 Pasal 3 UU Parpol. 
/kota sampai tahapan terakhir pemilihan umum; dan e) rekening atas nama partai politik. Selanjutnya keberadaan partai politik sebagai badan hukum dibuktikan berdasarkan Akta Pendirian Partai Politik yang didalamnya tercantum Anggaran Dasar dan Anggaran Rumah Tangga serta kepengurusan dari partai politik, sebagaimana tercantum dalam Pasal 2 ayat (3) dan ayat (4) UU Partai Politik.

Berdasarkan rumusan pasal tersebut, terlihat bahwa kelahiran partai politik sebagai badan hukum (rechtspersoon/legal entity) ada karena diciptakan atau diwujudkan melalui proses hukum (created by legal process) sesuai dengan ketentuan peraturan perundang-undangan. Oleh sebab itu, partai politik disebut badan hukum sesuai dengan teori kenyataan yuridis yang memahami keberadaan dan kapasitas dari badan hukum sebagai subjek hukum yang diciptakan berdasarkan hukum, yang mana ketentuan hukum yang menyatakan badan hukum atau korporasi sebagai subjek hukum yang dapat melakukan perbuatan serta memberikan hak dan kewajiban kepada badan hukum, sehingga badan hukum menjadi person standi in judicio atau subjek hukum mandiri.

Pengertian/definisi korporasi adalah bentuk paling umum dari organisasi bisnis, dan satu yang disahkan oleh negara dan diberikan banyak hak-hak hukum sebagai entitas terpisah dari pemiliknya. Bentuk bisnis ini ditandai dengan kewajiban terbatas pemiliknya, penerbitan saham dengan mudah dipindahtangankan dan kelangsungan hidup. Korporasi merupakan terminologi yang erat hubungannya dengan badan hukum (rechtsperson) dan badan hukum itu sendiri erat kaitannya dengan bidang hukum perdata. Secara etimologis, kata korporasi (corporatie, Belanda), corporation (Inggris), korporation (Jerman) berasal dari kata 'corporatio' dalam bahasa Latin. Seperti halnya dengan kata-kata lain yang berakhir dengan 'tio', maka 'corporatio' sebagai kata benda (substantivum), berasal dari kata 'corporare' yang dipakai pada jaman abad pertengahan atau sesudah itu 'corporare' sendiri berasal dari kata 'corpus' (badan, Indonesia), yang berarti memberikan badan atau membadankan. Dengan demikian 'corporatio' berarti hasil pekerjaan dari membadankan, dengan kata lain badan yang dijadikan orang, badan yang diperoleh dengan perbuatan manusia sebagai lawan terhadap badan manusia yang terjadi menurut alam. ${ }^{15}$

Menurut ketentuan dalam Pasal 1 ayat (1) UU Tipikor menyatakan bahwa korporasi adalah kumpulan orang dan/atau kekayaan yang terorganisasi baik merupakan badan hukum maupun bukan badan hukum. Penekanan pada kalimat dan/atau dalam ketentuan yang terdapat pada Pasal 1 ayat (1) tersebut memberikan arti menjadi beberapa jenis, yaitu: ${ }^{16}$

15 Muladi dan Dwidja Priyatno, Pertanggungjawaban Korporasi Dalam Hukum Pidana, Bandung: Sekolah Tinggi Hukum Bandung, 1991, hlm. 12.

16 R. Wiyono, Pembahasan Undang-Undang Pemberantasan Tindak Pidana Korupsi, Jakarta: Sinar Grafia, 2009, hlm. 21-22. 
a) Kumpulan orang dan kekayaan yang terorganisasi berbentuk badan hukum;

b) Kumpulan orang dan kekayaan yang terorganisasi yang bukan berbentuk badan hukum;

c) Kumpulan orang yang terorganisasi yang berbentuk badan hukum;

d) Kumpulan kekayaan yang terorganisasi yang bukan berbentuk badan hukum;

e) Kumpulan kekayaan yang terorganisasi yang berbentuk badan hukum; dan

f) Kumpulan kekayaan yang terorganisasi yang bukan berbentuk badan hukum.

Kemudian yang dimaksud korporasi yang terdapat dalam pengertian Pasal 1 ayat (1) UU Tipikor meliputi baik yang berbentuk badan hukum maupun yang tidak berbentuk badan hukum. Agar suatu korporasi dapat dikatakan sebagai badan hukum, terdapat doktrin yang menentukan pemenuhan syarat sebagai berikut: ${ }^{17}$

a) Adanya harta kekayaan yang terpisah;

b) Mempunyai tujuan tertentu;

c) Mempunyai kepentingan sendiri; dan

d) Adanya organisasi yang diatur.

Melihat pengaturan dalam UU Partai Politik dan UU Tipikor, maka secara jelas dan tegas menyatakan bahwa partai politik adalah badan hukum yang dapat dikategorikan sebagai korporasi.

Sementara itu, dalam lapangan hukum pidana mengenal banyak teori pemidanaan terhadap korporasi, yaitu:

\section{a. Doctrine of Identification (Teori Identifikasi)}

Teori ini menyatakan bahwa perbuatan/kesalahan pejabat senior (senior officer) diidentifikasi sebagai perbuatan atau kesalahan korporasi yang dalam arti sempit dapat diartikan bahwa hanya perbuatan pejabat senior yang dapat dipertanggungjawabkan oleh korporasi, dan dalam arti luas diartikan bahwa tidak hanya pejabat senior/direktur yang dapat dipertanggungjawabkan oleh korporasi tetapi juga agen dibawahnya. ${ }^{18}$ Teori identifikasi disebut juga pertanggungjawaban langsung, yaitu agar suatu korporasi dapat dibebani pertanggungjawaban pidana, sehingga yang melakukan tindak pidana tersebut harus dapat diidentifikasi terlebih dahulu dan dilakukan oleh orang yang merupakan 'directing mind' dari korporasi tersebut. Hal senada juga dikemukakan oleh Richard Card, yang menyatakan bahwa "the acts and state mind of the person are the acts and state of mind of corporation" (terjemahan bebas: tindakan atau kehendak direktur adalah tindakan atau kehendak korporasi). ${ }^{19}$

\footnotetext{
17 Ali Rido, Badan Hukum dan Kedudukan Hukum Perseroan, Perkumpulan Koperasi, Bandung: Alumni Bandung, hlm. 56.

18 Barda Nawawi Arief, Kapita Selekta Hukum Pidana, Bandung: Citra Aditya Bakti, 2013, hlm. 193.

19 Muladi dan Dwidja Priyatno, Op.cit., hlm. 21.
} 
Menurut Barda Nawawi Arief ${ }^{20}$ teori ini disebut juga teori/doktrin 'alter ego' atau 'teori organ' yang dapat diartikan secara sempit maupun secara luas. Dalam arti sempit (di Inggris) menyatakan bahwa hanya perbuatan pejabat senior atau otak korporasi yang dapat dipertanggungjawabkan kepada korporasi, kemudian dalam arti luas (di Amerika) menyatakan bahwa tidak hanya pejabat senior atau direktur tetapi agen dibawahnya bisa diidentifikasi sebagai perwakilan dari korporasi tersebut.

\section{b. Doctrine of Strict Liability}

Teori ini menyatakan bahwa pertanggungjawaban pidana dapat dibebankan kepada korporasi tanpa perlu membuktikan adanya kesalahan (kesengajaan atau kelalaian) pada korporasi. Doktrin ini diartikan sebagai liability without fault atau pertanggungjawaban pidana tanpa kesalahan. Pertanggungjawaban pidana dapat dibebankan kepada korporasi apabila dapat dibuktikan bahwa korporasi telah melakukan actus reus, yaitu melakukan perbuatan yang dilarang ketentuan pidana. Tindak pidana yang demikian disebut juga offences of strict liability atau offences of absolute prohibition. ${ }^{21}$ Menurut L.B. Curson, doktrin strict liability ini didasarkan pada alasan-alasan sebagai berikut: ${ }^{22}$

1) Adalah sangat esensial untuk menjamin dipatuhinya peraturan penting tertentu yang diperlukan untuk kesejahteraan sosial;

2) Pembuktian adanya mens rea akan menjadi sangat sulit untuk pelanggaran yang berhubungan dengan kesejahteraan sosial; dan

3) Tingginya tingkat bahaya sosial yang ditimbulkan oleh perbuatan yang bersangkutan.

Pendapat lain yang hampir mirip dikemukakan juga oleh Ted Honderich, bahwa dalil/alasan (premise) yang bisa dikemukakan untuk strict liability adalah: ${ }^{23}$

1) Sulitnya membuktikan pertanggungjawaban untuk tindak pidana tertentu untuk menghindari adanya bahaya yang sangat luas;

2) Sangat perlunya mencegah jenis-jenis tindak pidana tertentu untuk menghindari adanya bahaya yang sangat luas; dan

3) Pidana yang dijatuhkan sebagai akibat dari strict liability sangat ringan.

Menurut Russel Heaton dalam bukunya yang berjudul Criminal Law, strict liability adalah pertanggungjawaban perbuatan pidana dengan tidak mensyaratkan

20 Barda Nawawi Arief, Bunga Rampai Kewajiban Pidana, Bandung: Citra Aditya Bakti, 2002, hlm. 246.

21 Sutan Remy Sjahdeini, Pertanggungjawaban Pidana Korporasi, Jakarta: Grafiti Press, 2006, hlm. 78.

22 Muladi dan Dwidja Priyatno, Pertanggungjawaban Pidana Korporasi, Jakarta: Kencana, 2010, hlm. 107-108.

23 Ibid., hlm. 108-109. Lihat juga pendapat dari Mardjono Reksodiputro, "Tindak Pidana Korporasi dan Pertanggungjawabannya Perubahan Wajah Pelaku Kejahatan di Indonesia", Makalah, 2013, hlm. 9, yang menyatakan bahwa permasalahan hukum pidana yang menyangkut korporasi disebabkan karena perbuatan tindak pidana korupsi ini selalu dilakukan secara rahasia, sukar diketahui, dan seringkali para korbanpun tidak mengetahui kerugian yang dialaminya. 
adanya kesalahan pada diri pelaku terhadap satu atau lebih actus reus. ${ }^{24}$ Demikian juga Romli Atmasasmita menyatakan bahwa hukum pidana Inggris selain menganut asas 'actus non facit reum nis men sit rea' (a harmful act without a blame worthy mental state is not punishable), juga menganut pertanggungjawaban mutlak tanpa harus ada atau tidak adanya unsur kesalahan pada sisi pelaku pidana. ${ }^{25}$

\section{c. Doctrine of Viscarious Liability}

Doktrin ini memberikan pembenaran bagi pertanggungjawaban pidana kepada korporasi dengan cara pertanggungjawaban pidana yang dibebankan kepada seseorang atas perbuatan orang lain (the legal responsibility of one person for the wrongful acts of another). Biasanya doktrin ini berlaku dalam hal perbuatan yang dilakukan orang lain itu dalam rangka ruang lingkup pekerjaan atau jabatan. Dalam arti walaupun seseorang tidak melakukan suatu tindak pidana dan ia tidak mempunyai kesalahan dalam arti biasa, ia masih tetap dapat dipertanggungjawabkan. ${ }^{26}$ Meskipun persyaratan untuk membangun tanggung jawab pidana pengganti berbeda di seluruh sistem, dasar komponen kewajiban adalah bahwa: agen dari korporasi melakukan kejahatan; kejahatan dilakukan sementara individu bertindak dalam lingkup kerja mereka; dan kejahatan dilakukan dengan niat (tidak harus satu-satunya niat) untuk menguntungkan korporasi.

Pada dasarnya, doktrin vicarious liability didasarkan pada prinsip 'employment principle', yaitu majikan adalah penanggung jawab utama dari perbuatan buruh atau karyawan. Jadi dalam hal ini, terlihat prinsip 'the servant's act is the master act in law' atau yang dikenal juga dengan prinsip 'agency principle' yang berbunyi 'the company is liable for the wrongful acts of all its employees'. ${ }^{27}$ Oleh sebab itu, perlu dikemukakan bahwa dalam pembahasan mengenai doktrin vicarious liability ini mencakup juga pembahasan mengenai doctrine of delegation atau the delegation principle. ${ }^{28}$

\section{d. Doktrin of Agregation}

Doktrin ini memungkinkan agregasi atau kombinasi kesalahan dari sejumlah orang untuk diatribusikan kepada korporasi sehingga korporasi dapat dibebani pertanggungjawaban. Semua perbuatan dan semua unsur mental (sikap kalbu) dari berbagai orang yang terkait secara relevan dalam lingkungan perusahaan dianggap seakan-akan dilakukan oleh satu orang saja. Doktrin ini memperhatikan kesalahan sejumlah orang secara kolektif, yaitu orang-orang yang bertindak untuk dan atas

\footnotetext{
Russel Heaton, Criminal Law Textbook, London: Oxford University Press, 2006, hlm. 403.

Romli Atmasasmita, Perbandingan Hukum Pidana, Bandung: Mandar Maju, 1996, hlm. 76.

26 Sutan Remy Sjahdeini, Seluk Beluk Tindak Pidana Pencucian Uang dan Pembiayaan Terorisme, Jakarta: PT. Pustaka Utama Grafiti, 2004, hlm. 33-38.

27 Barda Nawawi Arief, Bunga Rampai..., Op.cit., hlm. 249.

28 Kristian, Hukum Pidana Korporasi Kebijakan Integral Formulasi Pertanggungjawaban Pidana Korporasi di Indonesia, Bandung: Nuansa Aulia, 2014, hlm. 65.
} 
nama suatu korporasi atau orang-orang yang bertindak untuk kepentingan korporasi yang bersangkutan. ${ }^{29}$

\section{e. The Corporate Culture Model (Company Culture Theory)}

Doktrin ini membenarkan pertanggungjawaban korporasi dilihat dari prosedur, sistem kerja, atau budaya kerjanya (the procedures, operating systems, or culture of company). ${ }^{30}$ Oleh karena itu, teori budaya korporasi ini sering juga disebut model sistem atau model organisasi (organisational of systems model). ${ }^{31}$ Kesalahan korporasi didasarkan pada struktur kerangka pengambilan keputusan internal. Budaya perusahaan didefinisikan sebagai sikap, kebijakan, aturan, tentu saja perilaku atau praktik yang ada dalam tubuh perusahaan secara umum atau pada bagian tubuh perusahaan di mana kegiatan yang relevan terjadi.

Teori budaya perusahaan menyatakan bahwa kewajiban organisasi difokuskan tepat pada kewajiban korporasi dalam dirinya sendiri. Teori ini berkaitan dengan kebijakan perusahaan, prosedur, praktik, dan sikap; rantai kekurangan dari perintah dan pengawasan; dan budaya perusahaan yang mentolerir atau mendorong tindak pidana. Jadi ketentuan yang disebut budaya perusahaan jatuh dalam rubrik kewajiban organisasi. ${ }^{32}$

Namun demikian, untuk tujuan menilai apakah perusahaan itu lalai, dapat dibuktikan oleh fakta bahwa tindak pidana itu secara substansial kurang memadainya manajemen perusahaan, pengawasan, atau pengawasan pelaksanaan satu atau lebih dari karyawan, agen, pejabat; atau kegagalan untuk menyediakan sistem yang memadai untuk menyampaikan informasi yang relevan di bidang hukum, dan dalam korporasi dapat ditemukan memiliki unsur kesalahan yang diperlukan, meskipun tidak ada satu individu memiliki unsur kesalahan, dengan melihat perilaku dari korporasi sebagai keseluruhan (yaitu dengan menggabungkan pelaksanaan sejumlah karyawan, agen, atau petugas). ${ }^{33}$ Jika elemen fisik suatu pelanggaran yang dilakukan oleh karyawan, agen, atau petugas dari perbuatan korporasi dalam lingkup aktual atau kejelasan kerja, atau dalam otoritas aktual di mana elemen fisik juga harus dikaitkan dengan badan hukum.

Unsur kesalahan dari kelalaian lainnya dapat dibuktikan dengan cara:

1) Jika niat, pengetahuan, atau kecerobohan merupakan unsur kesalahan dalam kaitannya dengan fisik unsur pelanggaran, bahwa unsur kesalahan harus

29 Kristian, Ibid., hlm. 70.

30 Barda Nawawi Arief, Bunga Rampai..., Op.cit., hlm. 251.

31 Ibid.

32 Allens Arthur Robinson, "Corporate Culture as a Basis for The Criminal Liability of Corporations", Paper prepared for the United Nations Special Representative of the Secretary-General on Human Rights and Business, February 2008, hlm. 6.

33 Barda Nawawi Arief, Kapita Selekta..., Op.cit., hlm. 197-198. 
dikaitkan dengan badan usaha yang tegas, secara diam-diam atau tersirat berwenang atau diizinkan dewan pengawas;

2) Sarana yang otorisasi tersebut atau izin dapat didirikan meliputi:

a. Membuktikan bahwa dewan badan direksi sengaja, sengaja/ceroboh dilakukan perilaku yang relevan/tegas, diam-diam/tersirat berwenang atau diizinkan dewan pengawas;

b. Membuktikan bahwa agen manajerial tinggi dari korporasi dengan sengaja, sengaja/ceroboh terlibat dalam perilaku yang relevan/tegas, diamdiam/tersirat berwenang atau diizinkan dewan pegawas;

c. Membuktikan bahwa budaya perusahaan ada dalam tubuh perusahaan yang diarahkan, mendorong, ditoleransi, atau menyebabkan ketidakpatuhan dengan ketentuan yang relevan; atau

d. Membuktikan bahwa badan hukum gagal menciptakan dan mempertahankan budaya perusahaan yang diperlukan sesuai dengan ketentuan yang relevan.

Dalam hal ini, direksi berarti tubuh (dengan apa pun nama yang disebut) melaksanakan otoritas eksekutif badan hukum. Budaya perusahaan berarti sikap, kebijakan, aturan, serta tentu saja perilaku atau praktik yang ada dalam tubuh perusahaan secara umum atau di bagian tubuh perusahaan di mana kegiatan yang relevan berlangsung. Agen manajerial yang tinggi berarti seorang karyawan, agen, atau petugas tubuh perusahaan dengan tugas tanggung jawab sehingga perilakunya mungkin cukup untuk dianggap mewakili kebijakan badan hukum itu. ${ }^{34}$

Salah satu hal yang paling sulit untuk dilakukan dalam menuntut korporasi (partai politik) adalah mengidentifikasi perbuatan personel partai politik itu menjadi perbuatan yang dapat dipertanggungjawabkan kepada partai politik tersebut. Apakah ketua partai, sekretaris partai, bendahara partai, atau kader partai yang mengendalikan partai tersebut. Karena kesulitan mengindentifikasi personel partai politik yang bisa dijadikan sebagai representasi dari partai politik tersebut, sehingga mengakibatkan kesulitan dalam pembuktian bahwa perbuatan korupsi personel partai tersebut bisa dimintakan pertanggungjawaban pidana kepada partai politik yang bersangkutan.

Akan tetapi menurut Penulis, terdapat teori pemidanaan yang lebih sederhana dan lebih mudah dalam menentukan bahwa partai politik tersebut harus bertanggung jawab terhadap tindakan atau perbuatan korupsi yang dilakukan personelnya, yaitu dengan menggunakan teori budaya perusahaan atau The Corporate Culture Model (Company Culture Theory), yang mana doktrin tersebut membenarkan pertanggungjawaban korporasi dilihat dari prosedur, sistem kerja,

34 Allens Arthur Robinson, Loc.cit. 
atau budaya kerjanya (the procedures, operating systems, or culture of company). ${ }^{35}$ Kesalahan korporasi didasarkan pada struktur kerangka pengambilan keputusan internal. Jika budaya partai politik yang dapat dilihat dari sikap, kebijakan, aturan, tentu saja perilaku atau praktik yang ada dalam tubuh partai secara umum atau di bagian tubuh partai cenderung melakukan tindak pidana korupsi, atau partai politik tersebut tidak memiliki prosedur yang memadai atau lalai dalam rangka pengawasan dan pencegahan personel partai untuk tidak melakukan korupsi, maka partai politik tersebut bisa dibebankan pertanggungjawaban pidana.

Berdasarkan teori pemidanaan terhadap korporasi yang dijelaskan sebelumnya, serta pengaturan dalam ketentuan mengenai pemidanaan korporasi yang diatur dalam Pasal 2 ayat (1) UU Tipikor yang menyatakan bahwa:

"Setiap orang yang secara melawan hukum melakukan perbuatan memperkaya diri sendiri atau orang lain atau suatu korporasi yang dapat merugikan keuangan negara atau perekonomian negara, dipidana penjara dengan penjara seumur hidup atau pidana penjara paling singkat 4 (empat) tahun dan paling lama 20 (dua puluh) tahun dan denda paling sedikit Rp. 200.000.000,00 (dua ratus juta rupiah) dan paling banyak Rp. 1.000.000.000,00 (satu milyar rupiah)", serta ketentuan Pasal 20 UU Tipikor yang menyatakan bahwa:

"Dalam hal tindak pidana korupsi dilakukan oleh atau atas nama suatu korporasi, maka tuntutan dan penjatuhan pidana dapat dilakukan terhadap korporasi dan/atau pengurusnya, kemudian dalam pengertian keuangan partai politik adalah semua hak dan kewajiban Partai Politik yang dapat dinilai dengan uang, berupa uang, atau barang serta segala bentuk kekayaan yang dimiliki dan menjadi tanggung jawab Partai Politik". ${ }^{36}$

Artinya, menurut pasal ini partai politiklah yang harus bertanggung jawab atas semua kekayaan yang dimiliki partai, sehingga partai politik bisa dimintakan pertanggungjawabannya atas segala hal yang berkaitan dengan keuangan, sumber pendanaan, dan sumber kekayaan partai. Sehingga korporasi dalam hal ini partai politik adalah suatu bentuk badan hukum yang bisa dimintai pertanggungjawaban pidana.

\section{Jenis Sanksi Pidana yang Dapat Dijatuhkan kepada Partai Politik yang Melakukan Tindak Pidana Korupsi dan Pencucian Uang} Berdasarkan Pasal 40 ayat (3) UU Partai Politik, partai politik dilarang:

a. menerima dari atau memberikan kepada pihak asing sumbangan

35 Barda Nawawi Arief, Bunga Rampai..., Op.cit., hlm. 251.

36 Pasal 1 ayat (5) UU Parpol. 
dalam bentuk apapun yang bertentangan dengan peraturan perundang-undangan;

b. menerima sumbangan berupa uang, barang, ataupun jasa dari pihak mana pun tanpa mencantumkan identitas yang jelas;

c. menerima sumbangan dari perseorangan dan/atau perusahaan/ badan usaha melebihi batas yang ditetapkan dalam peraturan perundang-undangan;

d. meminta atau menerima dana dari badan usaha milik negara, badan usaha milik daerah, dan badan usaha milik desa atau dengan sebutan lainnya; atau

e. menggunakan fraksi di Majelis Permusyawaratan Rakyat, Dewan Perwakilan Rakyat, Dewan Perwakilan Rakyat Daerah Provinsi, dan Dewan Perwakilan Rakyat Daerah Kabupaten/Kota sebagai sumber pendanaan partai politik.

Jika partai politik yang bersangkutan melanggar Pasal 40 tersebut, maka partai politik tersebut akan dituntut dengan Pasal 48 ayat (5) yang menyatakan bahwa dalam hal terjadi pelanggaran terhadap ketentuan sebagaimana dimaksud dalam Pasal 40 ayat (3) huruf b, huruf $c$, dan huruf $d$, pengurus partai politik yang bersangkutan dipidana dengan pidana penjara paling lama 1 (satu) tahun dan denda 2 (dua) kali lipat dari jumlah dana yang diterimanya. Aturan ini menyatakan bahwa penguruslah yang harus bertanggung jawab terhadap pelanggaran tersebut, sedangkan partai tidak ikut dibebankan pertanggungjawabannya.

Lalu kemudian muncul pertanyaan apabila pengurus yang melakukan korupsi dan menyetorkan hasil korupsinya ke partai, apakah partai dapat dibebankan pertanggungjawaban pidana atau tidak. Berdasarkan UU Partai Politik tidak jelas diungkapkan tentang pengurus partai politik, apakah pengurus di tingkat daerah, provinsi, atau di tingkat pusat. Identifikasi pengurus yang menjadi representatif dari partai politik menjadi sangat sulit dilakukan karena luasnya definisi dari pengurus partai. Hal ini dikarenakan tidak tertutup kemungkinan pengurus partai di tingkat daerah, provinsi, dan pusat melakukan tindak pidana korupsi. Dengan demikian, korupsi yang dilakukan partai politik melalui pengurus atau kadernya akan berhubungan dengan kepentingan pengurus dan kepentingan keuangan (pembiayaan) partai politik tersebut yang kemungkinan berasal dari perbuatan yang merugikan keuangan negara, suap, gratifikasi, penggelapan dalam jabatan, pemerasan, perbuatan curang, dan konflik kepentingan. ${ }^{37}$

Selanjutnya, Pasal 20 UU Tipikor menyatakan:

1) Dalam hal tindak pidana korupsi dilakukan oleh atau atas nama suatu korporasi, maka tuntutan dan penjatuhan pidana dapat

37 ICW, Loc. cit. 
dilakukan terhadap korporasi dan/atau pengurusnya;

2) Tindak pidana korupsi dilakukan oleh korporasi apabila tindak pidana tersebut dilakukan oleh orang-orang baik berdasarkan hubungan kerja maupun berdasarkan hubungan lain, bertindak dalam lingkungan korporasi tersebut baik sendiri maupun bersama-sama;

3) Dalam hal tuntutan pidana dilakukan terhadap suatu korporasi, maka korporasi tersebut diwakili oleh pengurus;

4) Pengurus yang mewakili korporasi sebagaimana dimaksud dalam ayat (3) dapat diwakili oleh orang lain;

5) Hakim dapat memerintahkan supaya pengurus korporasi menghadap sendiri di pengadilan dan dapat pula memerintahkan supaya pengurus tersebut dibawa ke sidang pengadilan;

6) Dalam hal tuntutan pidana dilakukan terhadap korporasi, maka panggilan untuk menghadap dan penyerahan surat panggilan tersebut disampaikan kepada pengurus di tempat tinggal pengurus atau di tempat pengurus berkantor; dan

7) Pidana pokok yang dapat dijatuhkan terhadap korporasi hanya pidana denda, dengan ketentuan maksimum pidana ditambah $1 / 3$ (satu pertiga).

Menurut Pasal 20 UU Tipikor tersebut dengan jelas menyatakan bahwa pengurus dan korporasi, dalam hal ini partai politik, adalah subjek hukum yang bisa diminta pertanggungjawaban pidananya dalam tindak hal melakukan tindak pidana korupsi dengan tuntutan. Selain itu, penjatuhan pidana dapat dilakukan terhadap korporasi dan/atau pengurusnya, sementara sanksi pidana pokok yang dapat dijatuhkan terhadap korporasi hanya pidana denda, dengan ketentuan maksimum pidana ditambah 1/3 (satu pertiga). Tetapi apabila uang atau hasil tindak pidana korupsi tersebut oleh pengurus dan kader partai politik yang bersangkutan disumbangkan ke partai politik, maka partai politik juga dapat dituntut dengan dugaan telah melakukan tindak pidana pencucian uang.

Pasal 3 Undang-Undang Nomor 8 Tahun 2010 tentang Pencegahan dan Pemberantasan Tindak Pidana Pencucian Uang (UU TPPU) mengatur bahwa TPPU merujuk pada setiap orang yang menempatkan, mengalihkan, membelanjakan, membayarkan, menghibahkan, menitipkan, membawa ke luar negeri, mengubah bentuk, menukarkan dengan mata uang atau surat berharga atau perbuatan lain atas harta kekayaan yang diketahuinya atau patut diduganya merupakan hasil tindak pidana sebagaimana dimaksud dalam Pasal 2 ayat $(1)^{38}$ dengan tujuan

38 Hasil tindak pidana yang dimaksud dalam Pasal 2 ayat (1) Undang-Undang Nomor 8 Tahun 2010 tentang 
menyembunyikan atau menyamarkan asal usul harta kekayaan. Terpidana TPPU dapat pidana penjara paling lama 20 (dua puluh) tahun dan denda pidana penjara paling lama 20 (dua puluh) tahun dan denda paling banyak Rp10.000.000.000,00 (sepuluh miliar rupiah).

Agar dapat menjangkau berbagai modus operandi penyimpangan keuangan negara atau perekonomian negara yang semakin canggih dan rumit, maka tindak pidana yang diatur dalam undang-undang ini dirumuskan sedemikian rupa sehingga meliputi perbuatan-perbuatan memperkaya diri sendiri atau orang lain atau suatu korporasi secara 'melawan hukum' dalam pengertian formil dan materiil. Dengan perumusan tersebut, pengertian melawan hukum dalam tindak pidana korupsi dapat pula mencakup perbuatan-perbuatan tercela yang menurut perasaan keadilan masyarakat harus dituntut dan dipidana.

Dalam UU Tipikor ini, tindak pidana korupsi dirumuskan secara tegas sebagai tindak pidana formil. Hal ini sangat penting untuk pembuktian. Dengan rumusan secara formil yang dianut dalam undang-undang ini, meskipun hasil korupsi telah dikembalikan kepada negara, pelaku tindak pidana korupsi tetap diajukan ke pengadilan dan tetap dipidana. Perkembangan baru yang diatur dalam undangundang ini adalah korporasi sebagai subjek tindak pidana korupsi yang dapat dikenakan sanksi. Hal tersebut tidak diatur dalam Undang-Undang Nomor 3 Tahun 1971 tentang Pemberantasan Tindak Pidana Korupsi. ${ }^{39}$

Salah satu alternatif untuk membebankan tanggung jawab pidana terhadap korporasi (partai politik) adalah melalui mekanisme hukum yang ada pada Pasal 6 , Pasal 7, dan Pasal 9 UU TPPU. Pasal 6 UU TPPU menyatakan:

1) Dalam hal tindak pidana pencucian uang sebagaimana dimaksud dalam Pasal 3, Pasal 4, dan Pasal 5 dilakukan oleh korporasi, pidana dijatuhkan terhadap korporasi dan/atau personel pengendali korporasi.

2) Pidana dijatuhkan terhadap korporasi apabila tindak pidana pencucian uang:

a) dilakukan atau diperintahkan oleh personel pengendali korporasi;

b) dilakukan dalam rangka pemenuhan maksud dan tujuan korporasi;

Pencegahan dan Pemberantasan Tindak Pidana Pencucian Uang (UU TPPU) adalah harta kekayaan yang diperoleh dari tindak pidana: korupsi, penyuapan, narkotika, psikotropika, penyelundupan tenaga kerja, penyelundupan migran, di bidang perbankan, di bidang pasar modal, di bidang perasuransian, kepabeanan, cukai, perdagangan orang, perdagangan senjata gelap, terorisme, penculikan, pencurian, penggelapan, penipuan, pemalsuan uang, perjudian, prostitusi, di bidang perpajakan, di bidang kehutanan, di bidang lingkungan hidup, di bidang kelautan dan perikanan, atau tindak pidana lain yang diancam penjara 4 (empat) tahun atau lebih.

39 Penjelasan Undang-Undang Nomor 31 Tahun 1999 tentang Pemberantasan Tindak Pidana Korupsi (UU Tipikor). 
c) dilakukan sesuai dengan tugas dan fungsi pelaku atau pemberi perintah; dan

d) dilakukan dengan maksud memberikan manfaat bagi korporasi.

Menurut Pasal 7 UU TPPU menyatakan:

1) Pidana pokok yang dijatuhkan terhadap korporasi adalah pidana denda paling banyak Rp100.000.000.000,00 (seratus miliar rupiah);

2) Selain pidana denda sebagaimana dimaksud pada ayat (1), terhadap korporasi juga dapat dijatuhkan pidana tambahan berupa:

a) pengumuman putusan hakim;

b) pembekuan sebagian atau seluruh kegiatan usaha korporasi;

c) pencabutan izin usaha;

d) pembubaran dan/atau pelarangan korporasi;

e) perampasan aset korporasi untuk negara; dan/atau

f) pengambilalihan korporasi oleh negara.

Kemudian menurut Pasal 9 UU TPPU menyatakan:

1) Dalam hal korporasi tidak mampu membayar pidana denda sebagaimana dimaksud dalam Pasal 7 ayat (1), pidana denda tersebut diganti dengan perampasan harta kekayaan milik korporasi atau personel pengendali korporasi yang nilainya sama dengan putusan pidana denda yang dijatuhkan;

2) Dalam hal penjualan harta kekayaan milik korporasi yang dirampas sebagaimana dimaksud pada ayat (1) tidak mencukupi, pidana kurungan pengganti denda dijatuhkan terhadap personel pengendali korporasi dengan memperhitungkan denda yang telah dibayar.

Selanjutnya, UU TPPU ini sudah sangat jelas memberikan sanksi kepada korporasi yang melakukan tindak pidana pencucian uang yang berasal dari tindak pidana korupsi, yaitu:

a. Sanksi denda;

b. Pengumuman putusan hakim;

c. Pembekuan sebagian atau seluruh kegiatan usaha korporasi;

d. Pencabutan izin usaha;

e. Pembubaran dan/atau pelarangan korporasi;

f. Perampasan aset korporasi untuk negara; dan/atau

g. Pengambilalihan korporasi oleh negara. 


\section{Penutup}

1. Kesimpulan

1) Penulis berpendapat bahwa partai politik dapat dikategorikan sebagai korporasi, yaitu subjek hukum yang dapat diminta pertanggungjawaban pidananya dalam hal personel atau pengurusnya melakukan tindak pidana korupsi berdasarkan teori pemidanaan terhadap korporasi, ketentuan dalam Pasal 2 Ayat (1) dan Pasal 20 UU Tipikor, serta ketentuan dalam Pasal 6 UU TPPU.

2) Bentuk sanksi yang dapat dibebankan kepada partai politik ada beberapa jenis, tergantung ketentuan mana yang digunakan. Jika menggunakan ketentuan dalam Pasal 20 UU Tipikor, maka bentuk sanksinya hanya pidana denda, dengan ketentuan maksimum pidana ditambah $1 / 3$ (satu pertiga), akan tetapi jika menggunakan ketentuan dalam Pasal 7 UU TPPU, maka bentuk sanksi dapat berupa: sanksi denda, pengumuman putusan hakim, pembekuan sebagian atau seluruh kegiatan usaha partai, pencabutan izin operasional partai, pembubaran dan/atau pelarangan partai, perampasan aset partai untuk negara, dan/atau pengambilalihan partai oleh negara.

2. Saran

1) Butuh keberanian dari aparat penegak hukum di Indonesia untuk membebankan pertanggungjawaban pidana dan menuntut partai politik apabila melakukan tindak pidana korupsi dengan berdasarkan teori pemidanaan korporasi, baik itu dengan doctrine of identification (teori identifikasi), doktrin vicarious liability, strict libility, teori agregat, dan teori budaya perusahaan. Akan tetapi, teori yang lebih sederhana dalam pembuktian bahwa partai telah melakukan tindak pidana korupsi adalah dengan menggunakan teori budaya perusahaan.

2) Jika pengurus partai politik melakukan tindak pidana korupsi dan dapat dibuktikan bahwa pengurus partai menyumbangkan hasil korupsinya ke partai politik, maka dapat digunakan mekanisme pada UU TPPU yang sudah menerapkan berbagai jenis sanksi, termasuk sanksi paling berat berupa pembubaran partai politik tersebut.

\section{Daftar Pustaka}

\section{Buku}

Ali Rido, Badan Hukum dan Kedudukan Hukum Perseroan, Perkumpulan Koperasi, Alumni Bandung, Bandung, Tanpa Tahun.

Barda Nawawi Arief, Bunga Rampai Kewajiban Pidana, Citra Aditya Bakti, Bandung, 2002. Kapita Selekta Hukum Pidana, Citra Aditya Bakti, Bandung, 2013. 
Firmanzah, Mengelola Partai Politik Komunikasi dan Positioning Ideologi Politik Di

Era Demokrasi, Pustaka Obor Indonesia, Jakarta, 2011.

Heaton, Russel, Criminal Law Textbook, Oxford University Press, London, 2006.

Kristian, Hukum Pidana Korporasi Kebijakan Integral Formulasi Pertanggungjawaban Pidana Korporasi di Indonesia, Nuansa Aulia, Bandung, 2014.

Muladi dan Dwidja Priyatno, Pertanggungjawaban Korporasi Dalam Hukum Pidana, Sekolah Tinggi Hukum Bandung, Bandung, 1991.

Pertanggungjawaban Pidana Korporasi, Kencana,

Jakarta, 2010.

R. Wiyono, Pembahasan Undang-Undang Pemberantasan Tindak Pidana Korupsi, Sinar Grafia, Jakarta, 2009.

Romli Atmasasmita, Perbandingan Hukum Pidana, Mandar Maju, Bandung, 1996.

Sutan Remy Sjahdeini, Pertanggungjawaban Pidana Korporasi, Grafiti Press, Jakarta, 2006.

, Seluk Beluk Tindak Pidana Pencucian Uang dan Pembiayaan Terorisme, PT. Pustaka Utama Grafiti, Jakarta, 2004.

Wirjono Prodjodikoro, Asas-Asas Hukum Pidana di Indonesia, Refika Aditama, Bandung, 2014.

\section{Dokumen Lain}

ICW, Modul Monitoring Penegakan Hukum, 2012.

http://www.antikorupsi.org/sites/antikorupsi.org/files/doc/Modul/modulmo nitoringpenegakanhukum.pdf

Arfan Faiz Muhlizi, "Revolusi Mental Untuk Membentuk Budaya Hukum Anti Korupsi", Jurnal Hukum RechtsVinding, Vol. 3, No. 3, 2014.

Mardjono Reksodiputro, "Tindak Pidana Korporasi dan Pertanggungjawabannya Perubahan Wajah Pelaku Kejahatan di Indonesia", Makalah, 2013.

Pukat, Seluruh Parpol Terlibat Kasus Korupsi, http://www.hukumonline.com/berita/baca/lt5329627e98607/pukat--seluruhparpol-terlibat-kasus-korupsi, diakses 22 Oktober 2015.

Robinson, Allens Arthur, "Corporate Culture as a Basis for The Criminal Liability of" Corporations", Paper prepared for the United Nations Special Representative of the Secretary-General on Human Rights and Business, February 2008.

Transparency International, "Corruption Perception Index 2014", http://www.ti.or.id/index.php/publication/2014/12/06/corruptionperceptions-index-2014, diunduh 20 Mei 2015.

\section{Dokumen Hukum}

Undang-Undang Nomor 30 Tahun 1999 tentang Pemberantasan Tindak Pidana Korupsi jo. Undang-Undang Nomor 20 Tahun 2001 tentang Perubahan atas 
Undang-Undang Nomor 31 Tahun 1999 tentang Pemberantasan Tindak Pidana Korupsi.

Undang-Undang Nomor 2 Tahun 2008 tentang Perubahan atas Undang-Undang Nomor 2 Tahun 2011 tentang Partai Politik.

Undang-Undang Nomor 8 Tahun 2010 tentang Pemberantasan Tindak Pidana Pencucian Uang.

Penjelasan Undang-Undang Nomor 31 Tahun 1999 tentang Pemberantasan Tindak Pidana Korupsi. 